\title{
Time to act: the UK in NATO
}

Article

Accepted Version

Risso, L. (2015) Time to act: the UK in NATO. RUSI Journal, 160 (5). pp. 30-34. ISSN 1744-0378 doi:

https://doi.org/10.1080/03071847.2015.1102540 Available at https://centaur.reading.ac.uk/44147/

It is advisable to refer to the publisher's version if you intend to cite from the work. See Guidance on citing.

Published version at: https://www.rusi.org/publications/journal/issue:I55D705B9BEDAD/

To link to this article DOI: http://dx.doi.org/10.1080/03071847.2015.1102540

Publisher: Routledge

All outputs in CentAUR are protected by Intellectual Property Rights law, including copyright law. Copyright and IPR is retained by the creators or other copyright holders. Terms and conditions for use of this material are defined in the End User Agreement.

\section{www.reading.ac.uk/centaur}

\section{CentAUR}

Central Archive at the University of Reading

Reading's research outputs online 
DOI: 10.1080/03071847.2015.1102540.

Once published online, the article will be available at: http://dx.doi.org/10.1080/03071847.2015.1102540

\title{
Time to Act: The UK in NATO Linda Risso, University of Reading
}

RUSI Journal, October 2015

\begin{abstract}
Since 1989, NATO has expanded its strategic concept and geopolitical scope to the detriment of an efficient and well-defined military capability in Europe. The Ukrainian crisis has brought the attention back to Europe and to NATO's deterrent value. As one of the Alliance's leading members, Britain must act as a catalyst to ensure that NATO has the necessary military strength and political will to respond to the new security challenges.
\end{abstract}

In his recent budget, Chancellor George Osborne announced that the UK will meet the pledge to spend 2 per cent of gross national product on defence for the rest of this decade. Defence spending will grow by 0.5 per cent per year, increasing from $€ 38$ billion this year to almost $£ 48$ billion in 2020. Cheers from Washington and Brussels welcomed the announcement. ${ }^{1}$ The UK will now enter a small club of five NATO members that meet the Alliance's target. US and NATO officials hope that other European allies will follow the British example and increase their defence budgets. ${ }^{2}$

A closer look at the small print however reveals a less encouraging picture. Osborne himself admitted that to meet the 2 per cent target, the UK will make full use of NATO's broad definition of 'defence spending'. The UK government already includes the cost of military pensions and overseas stabilisation missions in its defence budget. Now, there is the idea of adding some of the costs of the UK's surveillance and monitoring agencies. The government may also look into ways to redirect some resources from the Department for International Development to pay for some of the humanitarian work carried out by the armed forces. These are of course sensible and practical suggestions but if the aim is to make sure that the UK has an efficient, modern 
and capable army, and that - as a consequence - NATO does too, then something has been lost on the way.

The timing of the decision is important. After an initial phase in which the defence budget seemed to dominate the electoral campaign earlier this year, there was little mention of the issue during the actual run-up to the election and it did not figure in the Conservative manifesto. The new government announced the commitment as soon as it could after the election and in good time to shape the forthcoming Strategic Defence and Security Review (SDSR), due later this year. This is therefore a crucially important time to think about what role the UK hopes to play in the Alliance, in Europe and in the world.

The key issue is not merely the pledge to meet the 2 per cent figure but to make sure that NATO remains an effective political and military alliance able to deter any aggression, and able to take up a proactive role on the world stage. There is already a rather intense debate around the usefulness of the 2 per cent target. Critics have pointed out that it measures input not output, and that it does not necessarily give an indication of military capability, deployability and sustainability levels. Most crucially, it says nothing about the countries' resolve to deploy their forces on the ground and to take risks. Yet, the 2 per cent target remains politically significant as it is used - mostly by the US - to divide the European members between 'partners' and 'free-riders'. ${ }^{3}$ If the UK is to play an active political role in the Alliance and be included among the 'partners', it is essential that London shows itself willing to reverse the decrease in military spending and pledge to aim to meet the target. If, however, the ultimate aim is to modernise and make UK defence more effective, efficient and able to take up a leading role in the alliance, then jiggling with the budget is not the answer and the target itself is meaningless. The UK must contribute proactively to the Alliance's defensive and strategic roles as well as ensure that NATO's internal political cohesion is solid and resilient. In order to do so, the UK needs first to think about its place in Europe and, more broadly, about its own geopolitical role, its priorities and its foreign-policy goals. London should assess how such goals translate in terms of action and participation 
within the NATO framework. This article puts forward a few suggestions.

\section{NATO Today}

The Ukrainian crisis has brought the attention back to the European theatre and military deterrence. The Alliance has met its commitments under Article 4 and has reassured its members on the eastern flank which felt threatened by Russia. In April 2014, the US sent twelve F-16 fighters to Poland and ten F-15s to the Baltic States for air-patrols. ${ }^{4}$ Four British Typhoons joined them a year later. ${ }^{5}$ NATO has also dispatched Boeing E-3As to monitor Eastern European airspace. Moreover, in September, the first of six NATO Force Integration Units were inaugurated. These are designed to enable the fast deployment of the new NATO Response Force (NRF) in times of crisis. ${ }^{6}$ In October and November 2015, the largest NATO military exercise in the post-Cold War era (Trident Juncture, TJ15) is being hosted primarily by Italy, Portugal and Spain. TJ15 will involve 36,000 personnel from thirty Allied and Partner Nations. ${ }^{7}$ In addition, NATO has been liaising closely with the governments of Sweden and Finland. On 10 September, Russian concerns prompted the first-ever UN-Nordic Deputy Defence Ministers meeting. ${ }^{8}$

The problem is Article 5. Would NATO intervene if Russia carried out an asymmetric attack, or non-linear warfare that fell below the official definition of 'armed attack' specified by the Treaty? Once again, political cohesion is essential and, if needed, NATO must act quickly as one, fully committed alliance. If NATO does not achieve such level of political cohesion not only would it not be able to respond quickly and effectively to a possible attack but its very deterrent value would be nullified.

In this context, the question of political leadership is central. Even in the restricted scenario of the Ukrainian crisis, NATO members have not reached a workable agreement regarding what lines the diplomatic exchange with Russia should follow. Should they, for example, uphold the principles of the 1997 NATO-Russia Founding Act whereby the Alliance has 'no intention, no plan and no reason' to place significant military assets in ex-Warsaw Pact countries? Or should they take a strong stand on Russia's violation of international law and consider stationing troops and nuclear 
weapons in the territory of new members? Should the Alliance talk as one actor or should leading members - like Germany - take the lead? These points add to the already vitriolic discussion on whether NATO should expand further eastwards and on the alleged betrayal of Russia's trust over the past two decades. ${ }^{9}$ Political consensus within the Alliance is notably fragmented. Germany and Italy are keen to give priority to diplomatic negotiations while the UK and the US support the Baltic States' and Poland's calls for a firmer military stand. Of course, the Ukrainian crisis is only one of the security threats NATO and its members face today. Daesh (also known as the Islamic State of Iraq and Syria, ISIS) now controls large portions of Iraq and Syria. It controls an area that is larger than the UK. Similarly, Boko Haram now controls a more than half of Nigeria. South Sudan is in the middle of a civil war and instability persists in Darfur, Afghanistan, Pakistan and Somalia. Piracy still plagues the Gulf of Aden and millions of refugees are knocking of Europe's door. One could argue that these threats are not necessarily NATO's concern but they do challenge the security and stability of Europe, both directly - as the refugee crisis demonstrates - and indirectly - by fostering anti-Western terrorist groups and waging local wars that affect the security and stability of countries closely linked to some of the Atlantic Alliance's members.

These issues make the discussion of what the Alliance is for all the more urgent. It cannot do everything everywhere while hoping to have a strong and coherent voice on the world stage.

\section{The UK and NATO: A Need for Leadership}

The UK cannot afford to ignore the new security challenges and it cannot retreat into isolation. London has traditionally offered leadership both in international organisations and by taking upon itself to intervene in crisis situations, like in Sierra Leone. Because of its history and heritage, the UK is at the centre of a very important network of alliances, has unique insight into some of the key problems and geographical areas mentioned above, and has the military and diplomatic expertise that is essential to engage with a variety of actors, countries and concerns. Yet, it seems that over the past decade, the 
UK has lost the determination to act as a leader in the European arena.

Like many other European states, the UK assumed that in the post-Cold War environment, traditional military capabilities were no longer needed and that new, smaller, specialised tasks had to be developed. Political and economic stabilisation and crisis-management operations became the new priorities. The 1998 Strategic Defence Review (SDR) ${ }^{10}$ and the 2010 SDSR oversaw a progressive reduction and consolidation of British armed forces. ${ }^{11}$ In the context of the financial crisis and cuts in spending, the 2010 SDSR was particularly firm in reducing the $f 38$ billion overspend in the Ministry of Defence's procurement budget. ${ }^{12}$ Both documents were 'Treasury-led' and aimed primarily at reducing expenditure by consolidating resources. ${ }^{13}$ In the same period, the UK took part in several peacekeeping, humanitarian and disaster-relief operations under the auspices of the UN and NATO. ${ }^{14}$ At the time it was argued that despite the cuts, 'planned levels of defence spending should be enough for the United Kingdom to maintain its position as one of the world's top military powers, as well as being one of NATO-Europe's top military powers'.$^{15}$ Yet, it was clear that, in the long-term, the UK's status as a major power was set to be eroded and experts started to talk about 'overstretch' - in terms of both capability and of tasks - and about 'personnel retention' issues. The military's ability to fulfil the UK's overseas commitments in the long-term was brought into question. ${ }^{16}$

According to the recent Parliamentary Defence Committee report, the 2010 SDSR was unable to provide an insight into emerging security threats and international crises, and was an insufficient basis to build adequate military capabilities. ${ }^{17}$ In other words, the cuts did not allow for a geopolitical scenario involving state-on-state war in Europe or for complex responses to non-linear warfare. The issue is that while there have been spending cuts and rationalisation of resources, there has not been a re-think of the overall strategic focus and global goals underpinning UK defence and security policies. Instead, the UK continues to aim to maintain the full military capability of an advanced power (three full services, employing everything from tanks to the most modern fighter jets as well as nuclear weapons). The focus is also not restricted to a particular region 
and the ambition is to be able to engage globally. In this context, Osborne's statements should not cause excessive enthusiasm: a lot of the increased resources will be used to modernise and maintain current defence levels.

Yet, even if the actual impact of the new defence budget may be less than it suggests, the commitment to meet the 2 per cent target is an important political sign. It flags the UK's determination to be a reliable partner and to play a proactive role within the Alliance. It also reassures Washington that London remains its most important European partner. By meeting the target, the UK is now in a position to push other European allies to reverse the decrease in their defence spending and to lead the political debate about Europe's security strategy and geopolitical role.

It is not all doom and gloom. The UK remains an important member of NATO and it has indeed helped shape the alliance agenda in recent months. For example, the government hosted the Wales Summit in September 2014 and it was instrumental in mediating between the various partners to achieve political consensus behind the strengthening of the Rapid Reaction Force. The UK was also one of the first members to step forward and to provide a battle group and brigade headquarters to the new Very High Readiness Joint Task Force. Clearly, the UK is an active member. But is it a leader?

In NATO, the UK's most powerful ally remains the US. Yet, London must move away from the post-Cold war assumption that the US would be able - and willing - to compensate at least for some UK capability gaps given that London generally operates in coalition with its most powerful ally. This cannot be taken for granted and overreliance on this partnership may reduce the UK's room for manoeuvre. More than once, the US has expressed concerns about the fact that it contributes for 70 per cent of the Alliance's budget and US Defence Secretary Robert Gates famously warned the Europeans not to they rely on the US support and to invest more in defence. ${ }^{18}$ This also applies to the UK. Prior to Osborne's announcement, the US expressed openly concern that cuts in the UK defence budget would have an impact on UK-US co-operation. President Barack Obama himself called Prime Minister David Cameron in February 2015 to ask for the commitment to the 2 per cent figure and to have the UK play a more 
effective role in the Alliance. ${ }^{19}$ Thus, while there is no sign that the UK-US partnership is in danger, London should not take this for granted and it should make sure that it has a strong say in the Alliance. The UK needs to build once again on its position as a 'European' as well as an 'Anglo-Saxon' member of the Alliance so as to facilitate the dialogue between the two sides of the Atlantic about different priorities and security concerns. It is in a unique position to translate different strategic concerns and security priorities and to foster dialogue between Washington and the European capitals. This is what London did very well in the Cold War and it should aim to do this now. It would make the Alliance, as well as the partnership between the US and the UK stronger.

In Europe, the UK's strongest partner is France. The most recent phase of cooperation with the French goes back to the Lancaster House Treaties of 2010, which set up the Combined Joint Expeditionary Force. The best example of this collaboration was in Libya in 2011. The military operation at the time was efficient and effective. Unfortunately, there was no effort - or at least no success - in stabilising the country, which precipitated a new crisis. London should build on this co-operation. The French are keen and have expressed disappointment in the lack of enthusiasm of their partners. France's operation in Mali (Operation Barkhane) was a good example of how long-term country knowledge and a well-planned military engagement could stop state collapse and prevent a terrorist-affiliate takeover. This is something the many NATO partners should consider emulating.

NATO find itself at a crossroads in which it must decide what it wants to be. Emerging security challenges across the world and different threat perceptions within the Alliance, as well as a variety of national interests, mean that now, more than ever, NATO must decide its geopolitical scope and its priorities or it will not be in a position to respond to effectively to threats to national soverignity and integrity as well as nonlinear warfare attacks in Europe. The crisis in Ukraine shows this well.

The UK is at a crossroads too. London should lead the debate as it is uniquely placed to bring together the European allies and the US. It is also at the centre of longterm networks - including, but not limited to, the Commonwealth - that stretch well 
beyond the NATO area and Europe. This allows the country to have a broader and more sophisticated insight into emerging security challenges. Its long-term engagements mean that the UK also has long-standing expertise in the fields of counter-terrorism and humanitarian intervention. Hence, it is uniquely placed to offer leadership within NATO at a time when pragmatism, expertise and clear vision are badly needed. Yet to do that, the UK itself must decide what it wants to be and what it wants to achieve. It is ultimately, as always, a question of political leadership and assessment and it is essential that the UK resist the temptation to retreat into isolation or to proceed via bilateral agreements and special relationships.

It is in the interest of the UK and of its partners that the country takes full advantage of its unique position, alliances and expertise. This is the time to engage broadly and to put to good use the diplomatic channels offered by the Alliance. Political and diplomatic exchange among its members is what NATO does best and London should use it to stimulate the debate about the security and peace of Europe and of its neighbouring areas.

\section{Notes}

\footnotetext{
${ }^{1}$ Christopher Hope, “Barack Obama praises 'primary partner' Britain after David Cameron increased defence spending" The Telegraph, 14 July 2015.

${ }^{2}$ The countries that have pledged to meet the target are the US, Estonia, Greece, the UK and Poland.

${ }^{3}$ A detailed discussion on the limits of the $2 \%$ target has been carried out recently by the Carnegie Europe Foundation. Roundtable discussion on "The Cost of European security" with Malcom Chalmers, Douglas Lute, Jan Techau and Judy Dempsey on 17 September $2015 . \quad$ URL: http://carnegieeurope.eu/2015/09/17/cost-of-european-security/ihet (last accessed on 23 September 2015).

4 Ian Davis, "NATO to increase Baltic air patrols", NATO Watch, 9 April 2014. URL: http://www.natowatch.org/node/1456 (last accessed on 23 September 2015).

5 "Updated - Royal Air Force Typhoons fly in to Estonia for NATO Baltic Air Policing", Royal Air Force website, 13 May 2015. URL: http://www.raf.mod.uk/news/archive/updatedroyal-air-force-typhoons-flyin-to-estonia-for-nato-baltic-air-policing-13052015 (last accessed on 23 September 2015).

${ }^{6}$ The NATO Force Integration Units are located in Latvia, Bulgaria, Estonia, Lithuania, Poland and Romania. ${ }^{7}$ TJ15 will take place throughout Italy, Portugal, Spain, the Atlantic Ocean and the Mediterranean Sea. It will also include Canada, Norway, Germany, Belgium and the Netherlands. More than twelve major international organisations, aid agencies and non-governmental organisations, including the EU, will participate. Air, land, maritime and special forces will participate simultaneously in several locations and
} 
from different headquarters. See NATO, 'Trident Juncture 2015', <www.jfcbs.nato.int/tridentjuncture.aspx>, accessed 11 September 2015.

${ }^{8}$ At this point, NATO troops rotate depending on training and exercise needs. This arrangement has allowed NATO to fend off Russian criticism about the permanent stationing of troops in ex-Warsaw Pact members.

${ }^{9}$ There is an intense historiographical debate on this point, which is not possible to summarise here. For some of the key contributions, see Kristina Spohr, 'Germany, America and the Shaping of Post-Cold War Europe: A Story of German International Emancipation Through Political Unification, 1989-90', Cold War History (Vol. 15, No. 2, April 2015); Kristina Spohr, 'Precluded or Precedent-Setting? The "NATO Enlargement Question" in the Triangular Bonn-Washington-Moscow Diplomacy of 1990-1991', Journal of Cold War Studies, (Vol. 14, No. 4, Fall 2012); Mary Elise Sarotte, 1989: The Struggle to Create Post-Cold War Europe (Princeton, NJ: Princeton University Press, 2011).

${ }^{10}$ See Ministry of Defence (MoD), Delivering Security in a Changing World: Defence White Paper, CM 6041-I (London: The Stationery Office, 2003). This was written in the post-9/11 environment. It built upon the concepts of 'mobility' and 'expeditionary warfare' articulated in the 1998 Strategic Defence Review.

${ }^{11}$ HM Government, Securing Britain in an Age of Uncertainty: The Strategic Defence and Security Review (SDSR), Cm 7948 (London: The Stationery Office, October 2010).

${ }^{12}$ Initially, the Treasury asked the MoD to prepare options for a 10-20 per cent real-terms reduction in its budget. However, the final figure was a 7.7 per cent reduction over four years. See Nicholas Watt, 'Next Generation of Nimrod "Spy in the Sky" Surveillance Planes to be Scrapped', Guardian, 17 October 2010.

${ }^{13}$ David Chandler and lan Beckett (eds.), The Oxford History of the British Army (Oxford: Oxford University Press, 2010), p. 418. A Joint Rapid Reaction Force was formed in 1999, with tri-service resources at its disposal. See armedforces.co.uk, 'Permanent Joint Headquarters (PJHQ)', <www.armedforces.co.uk/mod/listings/l0006.html>, accessed 11 September 2015.

${ }^{14}$ The armed forces contributed, for example, to the international humanitarian and reconstruction efforts in the aftermath of the 2004 tsunami in Japan and the 2005 earthquake in Pakistan.

${ }^{15}$ Malcolm Chalmers, Looking into the Black Hole. Is the UK Defence Budget Crisis Really Over? - RUSI Briefing Paper. September 2011, p. 18.

${ }^{16}$ Andrew Dorman, 'Overstretch: Modern Army's Weakness', BBC News, 16 June 2005; and BBC News, 'Military "Faces Retention Crisis"', 5 January 2007.

${ }^{17}$ The Parliamentary Defence Committee published a report in which it specifically identified Russia as an 'advanced military nation' that posed a threat to the UK. See House of Commons Defence Committee, 'Re-Thinking Defence to Meet New Threats', HC 512, Tenth Report of Session 2014-15, 2015.

18 "Transcript of Defense Secretary Gates's Speech on NATO's Future", 10 June 2011, available on the Wall Street Journal website. URL: http://blogs.wsj.com/washwire/2011/06/10/transcript-of-defense-secretarygatess-speech-on-natos-future/ (last accessed on 23 September 2015).

${ }^{19}$ Francis Elliott and Deborah Haynes, 'Obama Urged Cameron not to Cut UK Defence Budget', The Times, 4 February 2015. 